\title{
Study on the Deviation of Women's Liberation Writing in Zhao Shuli's Works
}

\author{
Yan Long ${ }^{1, *}$
}

${ }^{1}$ School of Literature and Journalism, Sichuan University, Chengdu, Sichuan, China
${ }^{*}$ Corresponding author. Email: longyan-1986@163.com

\begin{abstract}
As a writer who received the "new learning" education, Zhao Shuli was influenced by the spirit of the May 4th Movement, however, the women writing in his works in the 1940s was somewhat biased. As a writer in the liberated area, the women writing of Zhao Shuli was influenced by the cultural environment at that time: The liberation of women in the liberated area was more to respond to the need for lack of productivity and the liberated women would bear more labor responsibilities. Therefore, Zhao Shuli emphasized the liberation of women under the reconstruction of the new order, which also made the women in his works have a "de-gendered" effect after liberation. In general, Zhao Shuli's writing about women's liberation was quite different from the women's liberation spirit, such as economic independence and spiritual independence, during May 4th Movement, and more merged with the political consciousness of the liberated area, therefore, it was more of a deviation.
\end{abstract}

\section{Keywords: Zhao Shuli, women's liberation, labor, deviation}

\section{INTRODUCTION}

In the "Speech at the Yenan Forum on Literature and Art" (hereinafter referred to as "Speech"), Mao Zedong put forward that literary creation should serve the "broad masses of the people" as well as "workers, peasants and soldiers" and the question of "how to serve them". In order to implement the spirit of "Speech", Zhao Shuli created a series of "lively and vivid works that were welcomed by the masses". There are many women images in these works, which have been involved in previous studies, and these figures are considered to be single, simple and ideological. But few people pay attention to the women's liberation and the deviation reflected in the writing of women's liberation embodied in Zhao Shuli's works. Zhao Shuli was born in a poor peasant family. When he went to Changye to study in a normal school in 1925, he began to receive western "new learning" education. In his school-days, he fell in love with new literature and art, and was enthusiastic about writing new poems and new novels. He belonged to a writer who grew up inspired by the spirit of the May 4th Movement.

Intellectuals during the May 4th Movement discussed the liberation of the women. Among them, Li Da's "On women's liberation" published under the name of $\mathrm{Li}$ Heming proposed that the women's liberation should consist of 7 aspects including the common education between men and women, the improvement of the marriage system, the spiritual independence of the women, and the economic independence of the women and so on, which was a more comprehensive article about women's liberation. Therefore, how does Zhao Shuli, who grew up inspired by the spirit of the May 4th Movement, write about women's liberation? What kind of deviation of him does it show in this process? This article focuses on Zhao Shuli's works such as "Xiao Erhei's Marriage", "Registration", "Do Exercise", "The Emancipation of Meng Xiangying" and "Family Heirloom", etc., and discusses how Zhao Shuli completed the writing of women's liberation under the dual requirements of the lack of productivity and the reconstruction of a new order and the deviations in his writing process.

\section{WOMEN'S LIBERATION UNDER THE SCARCE PRODUCTIVITY}

Productivity is the basis of social progress, and labor (the so-called labor refers to people with potential labor capacity) is the most important factor. After the outbreak of the anti-Japanese war, a large number of peasants went to the war front, resulting in a serious shortage of productivity in the rear production. Taking Sichuan as an example, the number of the enlisted in the anti-Japanese war is as follows ("Table I") [1]: 
TABLE I. THE NUMBER OF THE ENLISTED IN THE ANTIJAPANESE WAR

\begin{tabular}{|l|l|}
\hline \multicolumn{1}{|c|}{ Year } & The number of the enlisted \\
\hline 1937 & 103,837 \\
\hline 1938 & 174,145 \\
\hline 1939 & 296,341 \\
\hline 1940 & 266,373 \\
\hline 1941 & 344,601 \\
\hline 1942 & 366,625 \\
\hline 1943 & 352,681 \\
\hline 1944 & 391,112 \\
\hline 1945 & 283,086 \\
\hline Total & 2587,810 \\
\hline
\end{tabular}

Such was the situation with people's joining the army in the rear area in Szechwan, like that, a large number of young and middle-aged people in the liberated areas also joined the army during the same period to support the frontline war. This resulted in a labor shortage in the production process, which made production difficult.

In addition, as the anti-Japanese war entered a stalemate, by about 1940, the Shaanxi-GansuNingxia Border Region was facing economic blockade from the National Government of the Republic of China, and at the same time it was facing poor harvests caused by natural disasters and material shortages caused by the influx of a large number of foreign populations. The Chinese Communist Party was facing a serious economic crisis. In order to solve the crisis, around 1940, the Shaanxi-Gansu-Ningxia Border Region Government put forward the slogan of "Developing the Economy and Ensuring Supply" and carried out vigorous economic construction. Historically, it was called a great production campaign, and "the central link in the development of production was the organization of labor" [2]. The author believes that behind these is the demand for labor. In order to solve the problem of labor demand, the central government successively promulgated several policies calling on women to join the production. For example, Mao Zedong stated in his letter of instruction to the Central Women's Commission on February 8, 1940 that "Women's great role is first in the economy. Without them, production can't be proceeded. [3]" Zhu De called for "mobilizing the majority of women to the production campaign" at the Expanded Executive Committee of the Women's Federation of the Border Region at the end of 1940 [4]. Under the guidance of these policies, the liberated areas successively put forward the slogans of "Men Win Battles at the Frontline, Women Carry Out Large-scale Production at the Rear Area", and "Men Make War Merits at the Frontline, Women Make Wealth Merits at the Rear Area" [5]. The women are included in economic construction as potential labor. By the end of 1946, there were 1.5 million women in Mancheng County, Xushui County, Dingxing County, Yixian County, Laishui County and other counties of the west of Shanxi-ChaharHebei who took the place of militiamen to rush the harvest of autumn crops. By 1948, the participation of peasant women in the liberated areas in agricultural production accounted for $40 \%-50 \%$ [6] of the total number of working women, and they became the main source of labor in the liberated areas. Against the background of economic construction, Zhao Shuli paid more attention to the women's labor ability in his works, and believed that labor was an important way and content of women's liberation.

First of all, women broke free from the obstacles of the family - the feudal influence represented by the mother-in-law. Because Meng Xiangying had the ability to work, was an expert in labor, and was recognized as a labor hero, she began to "turn the tide" in family status. Facing the famine years, Meng Xiangying led the women to pick wild vegetables. "Meng Xiangying divided them into four groups and went up the mountain every day. Within a few days, all the edible leaves on the nearby mountains were all gone and were air-cured in the courtyards of these women. After picking the wild vegetables in their own village, they went to the other villages, and after the picking in the west of the river, they went to the east of the river, until the autumn wind sweeping away the withered. After calculating the general ledger, more than 20 women picked more than 60,000 catties of wild vegetables". [7] Because she needed to participate in productive labor, Meng Xiangying loosened her feet; because of productive labor, Meng Xiangying did what men did before collecting firewood and water. So far, the women image recognized by the mother-in-law that, "In her mind, she 'knows what an ideal daughter-in-law is like' - she combs a bun on her head, and has two dumpling feet; she makes tea, cooks, mills rice and flours, delivers soup and water, sweeps the floor and wipes the table... From pouring away the chamber pot early in the morning to making the bed at night, she should always be my side and on call at any time; when meeting a stranger, she is supposed to keep away from him immediately. If I don't tell outsiders, they won't know the existence of the daughter-in-law" [8] was subverted. The women got rid of the obstruction from the motherin-law.

Secondly, women entered the public living space through labor. Engels said in "The Origin of the Family, Private Ownership and the State" that "The first prerequisite for women's liberation is that all women return to public labor" [9]. Therefore, in Zhao Shuli's works, the ability of Meng Xiangying and Jin Gui to enter the public sphere is related to their ability to work. After Meng Xiangying became the director of the Women's Rescue Association, she led the work of women in the 
village on the basis of the conditions that she could work. "As soon as Meng Xiangying said that she planned to lead women to mow andropogon ischaemum, the family members of these women said: 'Hurry up and mow andropogon ischaemum with others. This woman has some ways." [10] Because she was able to work, her influence was beyond the village and she affected women's enthusiasm for labor in the entire area. Because of the need to organize women's labor in the entire village, Meng Xiangying went to a women's literacy class to learn culture, went to Taicang Village to participate in the spy fighting of Ren Erhai, and had a meeting to criticize the mothers-inlaw and husbands who beat and scolded their daughter-in-law. In these processes, Meng Xiangying was gradually liberated and moved towards the field of public life. In "Family Heirloom", Jin Gui also became the director of the Women's Federation because of her ability to work. In production, she often dealt with cooperatives, mutual aid teams, village offices and other public organizations. In the course of this interaction, she gradually participated in the public affairs of the whole village. At this point, Jin Gui also subverted the way the mother-in-law saw the daughter-in-law that, "Men have men's work, women have women's work, and if you ask me, I'd say that her labor look like a dog catching a mouse and being nosy. It's been a year since my son married her, how many times have she rotated the needle? How many times have she spun? [11]" It can be seen from this that women gradually walked out of the family in the process of participating in collective labor, expanded their social circles, participated in literacy classes, and learned spinning techniques. Women gradually gained economic and political cognition and were gradually liberated.

The emphasis on women's potential labor force made Zhao Shuli portray the mother-in-law as an image that hinders women's liberation when writing about this aspect. Looking at the oppression and enslavement of women in Chinese society, mothers-in-law are also victims. However, when Zhao Shuli wrote, he portrayed them as a symbol that hindered women's liberation, and at the same time didn't mention how they should be liberated. Mothers-in-law lost their labor force to till land and collect firewood due to factors such as being beaten and scolded by husband and foot-binding in the past society. Meng Xiangying's mother-in-law, after investigating the contents of the meeting of her daughter-in-law, came to the conclusion that "The two feet of the second daughter-in-law are not small enough no matter how they are bound with her being beaten and scolded. How dare she loosen them? What are women like when they fetch firewood and carry water? [12]" Regarding Jin Gui's mother-in-law, in the article, Zhao Shuli wrote, "Li Chengniang was originally a woman who was capable of doing a lot of work. Regardless of all seasons, she felt uncomfortable if she had nothing to do in her hands" [13]. From the description here, it can be inferred that the reason why Meng Xiangying's mother-in-law was in favor of binding feet was because she had already bound feet. During her entire life, Li Chengniang's main work was concentrated at home, and she mainly did manual work such as spinning (from the description about her appreciation for her daughter Xiao E's needlework and her three treasures in the article) told in the article. The labor of the mother-in-law was not in line with the reality of social production that women were called upon to participate in the social production after the young and middle-aged men joined the army, lacking agricultural production labor. Therefore, when Zhao Shuli wrote about women's liberation, he excluded these people from the list of women's liberation, and then regarded them as obstacles in the women's liberation movement.

Finally, with respect to labor and encouraging women to participate in labor, Zhao Shuli's works also involve criticism of women who do not participate in labor. In "Do Exercise", it talks about the reform of the two backward characters "Calf Pain" and "Hungry" by the Zhengxian Society to make them meet the goals and needs of socialist construction. The backwardness of the two characters was reflected in "choosing the easy way out", "being keen on gaining petty advantages" and "doing cheap jobs" in the process of labor. For example, "Calf Pain" "picked up wheat in summer, she went to the field when the wheat was not cut completely, however, when the wheat was finally cut, she didn't go [14]"; and after cutting wheat, when picking cotton, she went to pick cotton for several days continuously when the cotton was in full bloom and she could double the quota cotton. However, when the amount of cotton was just to match the quota, she didn't go to pick, even if the amount of cotton exceeded $30 \%$, she didn't go either" [15]. "Hungry" refused when she was mobilized in the group to participate in labor. Her reason was that "there was not enough food. She could only wait for Zhang Xin to finish eating and scraped an empty pot, so she really couldn't work" [16]. It can be seen that the unwillingness to participate in labor has become an important content of reforming backward people, and the unwillingness to participate in labor has risen to criticism of selfish thinking.

\section{WOMEN'S LIBERATION UNDER THE RECONSTRUCTION OF THE NEW ORDER}

As an economic and social outlet represented by Chinese society during the Republic of China, the new order established in the liberated areas required that all old traditions be overturned and a new 
civilized order including new class relations, new families, and new relations between men and women must be created. Therefore, it also adopted new policies to improve women's living conditions, and achieve equality between men and women, and freedom of marriage. When Zhao Shuli wrote about women's liberation, he naturally catered to the construction of this new order.

First of all, the new order must include the establishment of new leadership styles. When it is reflected in Zhao Shuli's works, it is showed through that the ultimate liberation of women is related to a fixed symbol - the staff. And the staff is the representative of the founder of the new order. The conflict between Jin Gui and her mother-in-law was completed with the help of her superior Xiao'e's husband. Xiao'e's husband "turned back and winked at Jin Gui and said, 'Jin Gui, don't get angry. Seriously, do you think so? "' [17]. Xiao'e's husband helped Jin Gui with her mother-in-law's thought work, and told her mother-in-law that she could no longer manage some new things. After Meng Xiangying became the director of the Women's Rescue Association, her mother-in-law still deliberately made things difficult, but Meng Xiangying felt that the staff was in charge, so she didn't care too much; if there was any problem at work, Meng Xiangying also asked the staff; when she learned that her mother-in-law was going to take and sell her to Xiangyuan, the staff also gave her an idea. In "Xiao Erhei's Marriage", when Xiao Qin knew that her mother was going to marry her to $\mathrm{Mr}$. Wu, Zhao Shuli wrote that she took the initiative to discuss with Xiao Erhei, and in the end, her getting the freedom of love and the autonomy of marriage was done with the help of the mayor (male)... Men are often rational and masculine, while women are often cowardly and pusillanimous. At some point, men have become a key factor in saving women.

Secondly, the new order also involves the establishment of a new view of marriage and love. For a long time, the Chinese marriages have always emphasized "perfect match", but in Zhao Shuli's works, it is shown in the struggle to complete women's autonomy in marriage and love to achieve the liberation of women in marriage as advocated by the new order. Zhao Shuli's "Xiao Erhei's Marriage" created in 1943 tells the story of the young Xiao Erhei and Xiao Qin fighting against remnants of feudal consciousness and bullies and fighting for the freedom of marriage. Among them, Xiao Qin's love for Xiao Erhei was born under the premise of revolution. Although the writer doesn't write much about the connection between Xiao Erhei and the revolution, from the introduction that "He once killed two enemies in 'repulsing the enemy's "mopping-up" campaign', and was rewarded as a crack shot", it can be inferred that
Xiao Qin's love for Xiao Erhei is not only because "Xiao Erhei puts on a play in the lunar January of every year, and no matter which village he goes to, women's eyes follow him everywhere". From this, it can be inferred that the establishment of their love is not only different from the feudal society's family status concept, but also different from the love of personal liberation and struggle during the May 4th Movement. It is based on national struggle and revolutionary war. [18] In addition, Zhao Shuli strengthened his expression in order to combine their love and struggle together. When Jin Wang went to bind Xiao Erhei, Xiao Erhei asked him, "Is it illegal to bind someone for no reason?" And when "Er Zhuge" gave Xiao Erhei a child bride, Xiao Erhei said to his father, "You can raise it if you want, I don't want her anyway." From these descriptions, it can be inferred that Xiao Erhei is a young man who grows up in struggle, and Xiao Qin's freedom to love and marriage is also completed in struggle. When Jin Wang decided to fight against Xiao Erhei, Xiao Qin took the chairperson of the Women's Rescue Association to meet the village head. After entering the door, she said, "The village head, if you want to catch a thief, you must find the stolen goods. If you want to catch the adultery, you must find the two persons involved. Are you brutal when you become the chairperson of the Women's Rescue Association?" [19] When "San Xiangu" was about to betroth Xiao Qin to Mr. Wu, Xiao Qin told her mother, "I don't care. Whoever takes things from him will go with him." [20] From these descriptions, it can be seen that the women's liberation written by Zhao Shuli is closely integrated with revolutionary struggle, and is a reflection of the power mechanism of a new order. It is also the presentation of the way of "revolution + love" written by the revolutionary writers. Meng Xiangying's "emancipation" in "The Emancipation of Meng Xiangying" is also mainly connected with the needs of collective production at that time. How Meng Xiangying walked away from her family has been discussed above. In this situation, the women's liberation written by Zhao Shuli was carried out with the establishment of a new order, which was simple and crude, not the liberation required by women after they realized the difference between men and women.

\section{DE-GENDERING AFTER WOMEN'S LIBERATION}

In a feudal society where men are superior to women, women receive unequal treatment from family and society. "The Book of Songs" mentions that "If you give birth to a boy, let him sleep on a big bed made of sandalwood, let him choose to wear beautiful clothes, and buy delicate jade for him to play". [21] This means that men receive preferential treatment from birth. "The Book of 
Rites. Hunyi" also records that the requirements for women's personal qualities are mainly four aspects including women's morality, women's words, women's appearance, and women's contribution. Women's living space is also realized in the family. With the introduction of Western thoughts, women's consciousness in China began to awaken and became aware of the oppression of feudal patriarchy from life. During the May 4th Movement, the torchbearers put forward a series of content involving women's liberation, including economic independence and spiritual independence. After the war broke out, the liberation of women was more about combining with the survival of the country and the nation. After combining Marxist thoughts on women's liberation with Chinese reality, Mao Zedong proposed that the liberation of working women was inseparable from the victory of the entire class. So far, the Communist Party of China has promulgated a series of programs for women's liberation, including the "Instructions of the People's Committee of the Chinese Soviet Republic", "Regulations on Prohibition of Women's Foot-binding," and "Decisions of the Central Committee of the Communist Party of China on the Current Work Guidelines for Women in AntiJapanese Base Areas". Among them, the "Decisions of the Central Committee of the Communist Party of China on the Current Work Guidelines for Women in Anti-Japanese Base Areas" promulgated in 1943 pointed out that "In the anti-Japanese base areas that are getting closer to victory with hardship, fighting, production and education are the three main tasks at present, and the vast number of rural women can and should make special efforts to participate in production. The efforts of women in production and the presence of able-bodied men at the front are equally glorious missions of fighting. And the improvement of women's political status, cultural level, and life in order to achieve the path of liberation, also needs to be started with economic prosperity and economic independence. Producing more and saving more, women and their families can live a good life, and they can also break free from feudal oppression. This is where the special interests of the vast number of rural women lie in the whole mass work, that is, the new direction of women's work in the anti-Japanese base areas". [22] Therefore, what Zhao Shuli portrays is the female image liberated under the dual requirements of economic production and new order reconstruction.

First of all, what is the image of women after liberation? In "The Emancipation of Meng Xiangying", Zhao Shuli used the grievances of Meng Xiangying's mother-in-law to portray a more definite image: (Meng Xiangying) had a round bun on her head, and her feet were getting bigger day by day. She tramped over hill and dale everyday without stop. A Jiaokou Village is not enough for her to go through, and she has to go through ten miles away. Instead of discussing with me about something to lie to the staff, she tells the staff everything..." [23] And Xiao'e's husband in "Family Heirloom" said, "If you women want to be truly liberated, you must do more, take care of more, and know more. After we go back, I should treat you like Jin Gui". [24] From this, it can be seen that Zhao Shuli believes that ideal women after liberation should be a group of people who can "participate in main labor", and the "main labor" involves labor content closely related to production and life. Taking Northwest Shanxi as an example, during the anti-Japanese war, the Women's Rescue Association organized and mobilized women to participate in production, "so that some women who never worked in the field would plant seeds in the field during spring ploughing; during the autumn harvest, some women were unable to stand up for a long time because of their small feet, so they tied a piece of cloth on their knees and knelt down on the ground to harvest hulless oat and dig Chinese yam". [25] Even when most of the cattle died due to lacking of forage because of drought in 1947, in Hejiazui, Wuzhai County, northwestern Shanxi, the "young women organized a commando team to cut grass, carry water, hoe, divide labor, and organize people to pull the plow" [26] to complete production. At this point, the image of women after liberation as a group with the ability to work has been fixed.

Secondly, according to Maslow's theory of needs, people will have higher-level needs after satisfying their basic needs. However, the new order didn't involve the content of women's needs in the promulgation of a series of women's liberation policies. Therefore, in the process of writing liberation, Zhao Shuli also ignored the psychological needs, emotional needs, safety needs and other needs of women, showing a tendency of simplification. In "Xiao Erhei's Marriage", San Xiangu could pursue new needs under the premise that the basic needs of her were satisfied. San Xiangu's pursuit of "beauty" was reasonable: When she was young, she "dressed more fashionably, combed her hair more smoothly, rubbed her jewelry more shinily, and applied her pearl powder more evenly" [27]; when she was old, she "preferred to be prettier, she still put embroidery on her small shoes and purfle on her trouser legs" [28]; in addition, she also loved being surrounded by young people, enjoyed the feeling of being surrounded by people, and appreciated the "beauty of Xiao Erhei". However, the writer ridiculed "San Xiangu" when he was creating, thinking that the elderly "San Xiangu" "looked like a donkey dung egg with frost" after makeup. [29] And San Xiangu's liking young people to surround her and her appreciation of Xiao Erhei were "flirtatious" in the writer's eyes, which was expressed by the ridicule of people around her. In "The Emancipation of Meng Xiangying", Meng 
Xiangying could work as hard as a man. Except for labor, Zhao Shuli basically didn't involve any other needs of Meng Xiangying; in "Family Heirloom", Jin Gui also basically had no other needs and other entertainment activities other than labor.

\section{CONCLUSION}

As a representative of literature of liberated area, Zhao Shuli inevitably merged with ideology when writing about women's liberation. First, the reality of the liberated areas is manifested in large areas of wasteland, labor shortages caused by wars, and meager grain production. Under such circumstances, women are often regarded and recognized as potential labor force and then they propose the rights that women should have - marriage autonomy and equality between men and women. Zhao Shuli was inevitably affected by this consciousness when he was writing, and he lacked understanding of women's liberation from the perspective of women themselves. Second, the new order power mechanism takes equality as its call and the slogan to eliminate inequality. Specifically to a family, it is required to achieve equality between men and women in the family, and this kind of equality is reflected in and completed in labor. The women's liberation presented in this situation is a simplistic meaning that doesn't involve the gender distinction of men and women and equates the women's liberation with the same status of men and women. Therefore, when Zhao Shuli wrote about women's liberation, he inevitably couldn't avoid expounding from an ideological point of view, and finally equated women's liberation with economic autonomy and freedom of marriage without touching the gender liberation from the cultural and psychological level.

Looking back at China's women's liberation movement, there were two climaxes, one was during the May 4th Movement and the other was during the liberated areas period. During the May 4th New Culture Movement, as torchbearers of new ideas, they put forward various aspects of women's liberation, which included the request for women's spiritual independence, women's economic independence, the implementation of ordinary elections for men and women, and the abolition of family vices. And Lu Xun, who had profound ideological insights, also proposed that women's liberation "in the current society, economic power was the most important. First, women should be given an equal share of men at home; second, in society, women should have equal power as men". [30] The intellectuals during the May 4th Movement were more concerned with women's liberation from the acquisition of power from the perspective of both sexes. However, Zhao Shuli, who was influenced by the "May 4th Movement" spirit in his life and in liberated areas, focused more on the status quo in the liberated areas when writing about women's liberation, which made it inevitable for him to have certain deviations when writing.

\section{References}

[1] Sichuan Society of Chinese Economic History. The Rear Economy During the Anti-Japanese War. [M] Chengdu: Sichuan University Press, 1989.04:161. (in Chinese)

[2] Mao Zedong. Organize [M]/ /Selected Works of Mao Zedong: Volume 3. Beijing: People's Publishing House, 1991: 928. (in Chinese)

[3] Hunan Women's Federation. Mao Zedong and the Liberation of Chinese Women [M] Changsha: Hunan Education Press, 1994.06:18. (in Chinese)

[4] Zhu De. Mobilize Women to the Production Movement [N] Women of China, 1941-1-8. (in Chinese)

[5] Hunan Women's Federation. Mao Zedong and the Liberation of Chinese Women $[\mathrm{M}]$ Changsha: Hunan Education Press, 1994.06:25. (in Chinese)

[6] Wang Guomin. Chinese Women in the 20th Century [M] Chengdu: Sichuan University Press, 2000:278. (in Chinese)

[7] Written by Zhao Shuli; edited by Lin Xianbi, Liu Jingchun. Zhao Shuli's Master Work, Zhengzhou: Henan People's Publishing House, 1986.08:72. (in Chinese)

[8] Written by Zhao Shuli; edited by Lin Xianbi, Liu Jingchun Zhao Shuli's Master Work, Zhengzhou: Henan People's Publishing House, 1986.08:73. (in Chinese)

[9] Edited by the All-China Women's Federation. Marx, Engels, Lenin and Stalin on Women. Beijing: People's Publishing House, 1978:128. (in Chinese)

[10] Written by Zhao Shuli; edited by Lin Xianbi, Liu Jingchun. Zhao Shuli's Master Work, Zhengzhou: Henan People's Publishing House, 1986.08 :72. (in Chinese)

[11] Written by Zhao Shuli; edited by Lin Xianbi, Liu Jingchun. Zhao Shuli's Master Work, Zhengzhou: Henan People's Publishing House, 1986.08:267. (in Chinese)

[12] Written by Zhao Shuli; edited by Lin Xianbi, Liu Jingchun Zhao Shuli's Master Work, Zhengzhou: Henan People's Publishing House, 1986.08:68. (in Chinese)

[13] Written by Zhao Shuli; edited by Lin Xianbi, Liu Jingchun. Zhao Shuli's Master Work, Zhengzhou: Henan People's Publishing House, 1986.08 :263. (in Chinese)

[14] Written by Zhao Shuli; edited by Lin Xianbi, Liu Jingchun. Zhao Shuli's Master Work, Zhengzhou: Henan People's Publishing House, 1986.08:312. (in Chinese)

[15] Written by Zhao Shuli; edited by Lin Xianbi, Liu Jingchun. Zhao Shuli's Master Work, Zhengzhou: Henan People's Publishing House, 1986.08:312. (in Chinese)

[16] Written by Zhao Shuli; edited by Lin Xianbi, Liu Jingchun. Zhao Shuli's Master Work, Zhengzhou: Henan People's Publishing House, 1986.08 :314. (in Chinese)

[17] Written by Zhao Shuli; edited by Lin Xianbi, Liu Jingchun. Zhao Shuli's Master Work, Zhengzhou: Henan People's Publishing House, 1986.08 :272. (in Chinese)

[18] Huang Xiuyi. Research Materials of Zhao Shuli [M] Taiyuan: Shanxi People's Publishing House, 1985:5. (in Chinese)

[19] Written by Zhao Shuli; edited by Lin Xianbi, Liu Jingchun Zhao Shuli's Master Work, Zhengzhou: Henan People's Publishing House, 1986.08 :8. (in Chinese)

[20] Written by Zhao Shuli; edited by Lin Xianbi, Liu Jingchun. Zhao Shuli's Master Work, Zhengzhou: Henan People's Publishing House, 1986.08 :8. (in Chinese) 
[21] Wang Guomin. Chinese Women in the 20th Century [M] Chengdu: Sichuan University Press, 2000:40. (in Chinese)

[22] Liberation Daily, February 26, 1943. (in Chinese)

[23] Written by Zhao Shuli; edited by Lin Xianbi, Liu Jingchun. Zhao Shuli's Master Work, Zhengzhou: Henan People's Publishing House, 1986.08: 74. (in Chinese)

[24] Written by Zhao Shuli; edited by Lin Xianbi, Liu Jingchun. Zhao Shuli's Master Work, Zhengzhou: Henan People's Publishing House, 1986.08 :274. (in Chinese)

[25] Edited by Shanxi Women's Federation. The Fighting Course of Women in Jin-Sui [M]] Beijing: Chinese Communist Party History Publishing House, 1992.05:119. (in Chinese)

[26] Edited by Shanxi Women's Federation. The Fighting Course of Women in Jin-Sui [M]] Beijing: Chinese Communist Party History Publishing House, 1992.05:143. (in Chinese)

[27] Written by Zhao Shuli; edited by Lin Xianbi, Liu Jingchun. Zhao Shuli's Master Work, Zhengzhou: Henan People's Publishing House, 1986.08 :3. (in Chinese)

[28] Written by Zhao Shuli; edited by Lin Xianbi, Liu Jingchun. Zhao Shuli's Master Work, Zhengzhou: Henan People's Publishing House, 1986.08 :3. (in Chinese)

[29] Written by Zhao Shuli; edited by Lin Xianbi, Liu Jingchun. Zhao Shuli's Master Work, Zhengzhou: Henan People's Publishing House, 1986.08 :3. (in Chinese)

[30] Women's Movement Director Research Office of AllChina Women's Federation. Selected Works on Women's Liberation Issues During the May 4th Movement [M] Beijing: SDX Joint Publishing Company, 1981.12:116. (in Chinese) 